\title{
Wyrok Sądu Metropolitalnego w Katowicach (c. Sobański) z 21.12.2004 z tytułu niezdolności pozwanej do podjęcia istotnych obowiązków małżeńskich
}

Ius Matrimoniale 10 (16), 221-226

2005

Artykuł został opracowany do udostępnienia w internecie przez Muzeum Historii Polski w ramach prac podejmowanych na rzecz zapewnienia otwartego, powszechnego i trwałego dostępu do polskiego dorobku naukowego i kulturalnego. Artykuł jest umieszczony w kolekcji cyfrowej bazhum.muzhp.pl, gromadzącej zawartość polskich czasopism humanistycznych i społecznych.

Tekst jest udostępniony do wykorzystania w ramach dozwolonego użytku. 


\section{Wyrok Sądu Metropolitalnego w Katowicach (c. Sobański) z 21.12.2004 z tytułu niezdolności pozwanej do podjęcia istotnych obowiązków małżeńskich}

\section{Przebieg sprawy:}

WK oraz SN zawarli małżeństwo 21.9.1985 w kościele św. Michała w O. Ważność tego małżeństwa zaskarżyła SN 22.3.1991 w Sądzie Kościelnym w S. Sprawę rozpatrywano z tytułu niezdolności pozwanego do podjęcia istotnych obowiązków małżeńskich oraz z tytułu symulacji powódki. Wyrokiem z 30.8.1994 Sąd ten orzekt, że nie udowodniono nieważności małżeństwa $\mathrm{z}$ żadnego $\mathrm{z}$ rozpatrywanych tytułów. Ponownie zaskarżyła swe małżeństwo SN dnia 19.5.1995 „z tytułów: 1) poważnego braku rozeznania oceniającego mężczyzny co do istotnych praw i obowiązków małżeńskich, 2) uzależnienia psychicznego mężczyzny od matki i rodziny, 3) niezdolności mężczyzny do podjęcia istotnych obowiązków małżeńskich". Skarga została oddalona dekretem oficjała z 6.7.1999. Zwrócil on uwagę, że tytuly podane w p. 2 i 3 są tożsame, a skarga z tego tytułu została już oddalona. Trybunał kolegialny tegoż Sądu utrzymał decyzję Oficjała w mocy 24.10.1995. Dnia 21.6.1999 skarga WK o orzeczenie nieważności małżeństwa z tytułu niezdolności kobiety do podjęcia istotnych obowiązków małżeńskich. Skarge przyjęto do procesu 12.7.1999. Przedmiot sporu ustalono zgodnie ze skargą. Wyrokiem z 3.12.2001 Sąd orzekł, że nie udowodniono nieważności małżeństwa. Wskutek apelacji pozwanej sprawa znalazła się w Trybunale II instancji. Trybunał ten rozpatrywał sprawę z tytułu zarówno niezdolności mężczyzny jak też niezdolności kobiety do podjęcia istotnych obowiązków małżeńskich. Wyrokiem z 7.10.2003 Trybunał II instancji orzekł, że nie udowodniono nieważności małżeństwa z tytułu niezdolności mężczyzny, udowodniono ją natomiast z tytułu niezdolności kobiety do podjęcia istotnych obowiązków małżeńskich. W części dotyczącej tego tytulu uchylono tym samym wyrok Trybunalu I instancji. Na prośbę pozwanej Najwyższy Trybunał Sygnatury Apostolskiej reskryptem z 18.5.2004 wyznaczył Sąd Metropolitalny w Ka- 
towicach do rozpatrzenia sprawy w trzeciej instancji. Akta sprawy nadeszly 22.6.2004. Obydwie strony wniosły o zatwierdzenie wyroku II instancji, nie przedkładając nowych wniosków dowodowych. Sąd zarządził kolejne przesłuchanie pozwanej. Dekretem z 25.11.2004 nastąpiło zamknięcie postępowania dowodowego. Obecnie przystępuje do rozsądzenia sprawy i odpowiada na pytanie procesowe jak następuje.

\section{Prawny i faktyczny stan sprawy:}

1. Normy prawa, mające zastosowanie w rozpatrywanej sprawie, wyłożono wystarczająco jasno w dotychczasowych wyrokach i nie zachodzi potrzeba ich powtarzania.

2. Przebieg sprawy zaskarżonej najpierw przez powódkę, potem przez pozwanego ale przy wyraźnej inicjatywie procesowej powódki, nastręcza pytanie, czy nie mamy tu do czynienia $z$ jej forsowaniem ,za wszelką cenę". W zeznaniach (wtedy) powódki złożonych w pierwszym procesie nie ma nawet śladowej wzmianki sugerującej jej przekonanie o własnej niezdolności do podjęcia istotnych obowiązków małżenskich. Co więcej, także zeznając w drugim procesie, prowadzonym $\mathrm{z}$ tytułu jej niezdolności, (teraz) pozwana mówi, że nie sprawiała żadnych klopotów wychowawczych, jest zdolna do podejmowania samodzielnych decyzji, jest pozytywnie ustosunkowana do innych osób oraz zdolna do poświęceń dla osoby kochanej, ma prawidlowy stosunek do mężczyzn... W trakcie drugiego procesu, prowadzonego już z tytułu jej niezdolności, biegły badający pozwaną ani nie dowiedział się ani nie stwierdził żadnych czy to faktów czy to cech, które mogłyby uzasadnić twierdzenie o jej niezdolności. Ekspertyza została sporządzona zgodnie $z$ regulami sztuki i udziela jasnej odpowiedzi na postawione pytania, a te dotyczyły właśnie zdolności pozwanej do podjęcia istotnych obowiązków małżeńskich.

W piśmie apelacyjnym do Trybunału II instancji napisała pozwana, że „bardzo wielu istotnych rzeczy” nie powiedziała ani w Sądzie ani psychologowi. Twierdzi, że dopiero gdy zwróciła się o poradę do psychologa-psychoterapeuty zrozumiala wlasne problemy, a w trakcie procesu nie była ,przygotowana psychicznie do mówienia o tych bolesnych doświadczeniach". W kolejnych, trzecich już, złożonych „po kontakcie z psychologiem” zeznaniach twierdzi: „Jedyna przyczyna rozpadu naszego matzeństwa byly przyczyny natury psychoseksualnej po mo- 
jej stronie. Ja $w$ tej dziedzinie bytam jeszcze niedojrzata pomimo wieku. Co byto ostateczna przyczyna tego, ja nie wiem. Ja miatam jakieś zahamowania. Może przyczyna byto to, że bedac w szkole średniej nauczyciel obejmowat mnie, proponowat mi spotkania, stawiat mi niedwuznaczne propozycje. Między nami nie zaistniata więź matżeńska”. Ową „możliwą przyczynę" biegły powołany w II instancji opisuje następująco: „W okresie nauki w szkole średniej pozwana przeżyla traumatyczne emocjonalnie doświadczenie, którego konsekwencje, zważywszy na okres rozwojowy (dorastanie-kształtowanie się osobowości), w którym wówczas byla, jak sie okazato, byly znamienne w przyszlości. Jak wynika z relacji pozwanej, byta ona „obiektem”, niedwuznacznych, o charakterze seksualnym, oddziaływań jednego z nauczycieli, zarówno na terenie szkoly (po lekcjach), jak i u niego w domu, gdzie była pod pretekstem pomocy w nauce zwabiana. Pozwana opisuje te zdarzenia jako wyjatkowo przykre i cięzkie przeżycie, wobec którego czuta sie zupetnie bezradna i osamotniona. $Z$ cata pewnościa wptynęto ono ograniczajaco, a nawet hamujaco, na jej gotowość do podejmowania kontaktów intymnych z innymi męzczyznami, w tym także z powodem, już w matżeństwie". W konkluzji biegły pisze o „nieprawidłowościach osobowościowych” w postaci zaburzeń stresowych pourazowych i zaburzeń adaptacyjnych, które w istotny sposób ograniczaly zdolność pozwanej do podjęcia i skutecznego wypelnienia istotnych obowiązków malżeńskich”. Do tej opinii przychylił się nawet obrońca węzla małżeńskiego Trybunału II instancji. Trybunał ten orzekając nieważność małżeństwa wskazał na „traumatyczne emocjonalne doświadczenie" pozwanej w szkole średniej, orzekł, że „decyzja kobiety na małżeństwo nie była dojrzała, a także nie w pełni świadoma i dobrowolna”, doszedł do wniosku, że „kobieta miała w tym czasie poważne braki w zakresie umiejętności samodzielnego prowadzenia gospodarstwa domowego, ponieważ mąż w tym czasie przebywał w wojsku, nie podjęto tych obowiązków", zwrócił uwagę, „małżeństwo stron trwało zaledwie około 10-miesięcy, w tym czasie mężczyzna przebywał w wojsku, nie wytwarzała się między stronami głębsza więź małżeńska, kobieta nie podjęła wysiłku jej tworzenia”, a po rozstaniu „nie podjęła wystarczających prób ratowania tego małżeństwa".

3. Wniosek wyprowadzony w wyroku Trybunału II instancji budzi jednak wątpliwości, zarówno logiczne jak i rzeczowe. Logiczne - gdyż trudno wnosić o niezdolności do podjęcia obowiązków związanych ze wspólnym gospodarstwem domowym, skoro mąż przebywał wtedy 
w wojsku, podobnie niezrozumiały jest zarzut, że pozwana nie podjęla wysiłku tworzenia głębokiej więzi małżeńskiej właśnie w tym czasie. Wątpliwości rzeczowe dotyczą argumentu z owego „traumatycznego przeżycia emocjonalnego". Sąd rozpatrując sprawę nie może traktować wcześniejszych akt jakby ich nie było. Są tam przecież zaprzysiężone zeznania, jest opinia biegłego sądowego, oceniając materiał dowodowy nie wolno ich pominąć, a rozbieżności nie wolno przemilczać, lecz trzeba je wyświetlić.

4. Sąd usilował wyświetlić oczywiste rozbieżności i rozwiązać wątpliwości licząc na wyjaśnienia pozwanej. Przesłuchana kolejny raz twierdzi, że tak podczas przesłuchania jak i u biegłych zawsze mówila prawdę, lecz za każdym razem była pytana o inne zagadnienia. Jednak w trakcie pierwszego procesu pozwana (wtedy powódka) zeznala: „Dopelniliśmy nasze małżeństwo po ślubie, ale nie od razu, bo naprawdę byłam niedysponowana, ale dopiero po pięciu dniach. Był to mój pierwszy stosunek $z$ mężczyzną. Dopełniliśmy nasze małżeństwo z obopólnej inicjatywy. Nie jest prawdą, że odmawiałam pozwanemu powinności małżeńskiej. Było to tylko raz, powiedziałam, że źle się czuję". Tak samo zeznawała w drugim procesie, dodając, że ,problemy były wokól współżycia”, co tłumaczyla wtedy niedostatkiem czasu, gdy mąż przyjeżdżał na przepustki. Również u biegłego przyznała, że „odmowa wspólżycia seksualnego wynikala z naturalnych fizjologicznych zjawisk", wskazała też na to, że ,mieli dla siebie malo czasu”. Za każdym razem jest też mowa o wpływie na dalsze pożycie ,przeraźliwego bólu", jakiego doznała przy dopelnieniu małżeństwa. Pytana przeto, co faktycznie zaważyło, ów ból czy owe „traumatyczne przeżycie”, odpowiada, że „na współżycie wplynęły oba wydarzenia: przedślubne i poślubne".

Skonfrontowana z własnymi weześniejszymi twierdzeniami o swej zdolności do wypełniania obowiązków małżeńskich pozwana twierdzi, że wcześniej nie zdawała sobie sprawy z tej niezdolności, gdyż dopiero psycholog uświadomił ją o niej, dlatego uważała się za zdolną.

Bezsporne jest, że można być niezdolnym do podjęcia i wypełnienia istotnych obowiązków małżeńskich nie zdając sobie z tego sprawy czy nawet uporczywie utrzymując, jakoby było się zdolnym. Trzeba jednak wskazać, dlaczego i do czego nupturient był niezdolny. Istotna - i jedyna - przyczyna niezdolności pozwanej to wedlug biegłego II instancji „traumatyczne przeżycie” w szkole. Trybunał II instancji przyjął w wyroku opis sporządzony przez bieglego. Trudno jednak oprzeć się wąt- 
pliwościom, czy przeżycie to było rzeczywiście tak silne i dalekosiężne w skutkach, skoro pozwana dlugo o nim nie pamiętała. Byłby to więc uraz nieuświadomiony, wydobyty dopiero przez drugiego psychologa, a dotyczyłby spółkowania. Jednak wedle własnych zeznań pozwanej owe przeżycia szkolne to obejmowanie, propozycje spotkania i propozycje „niedwuznaczne”, nie zaistniały jakieś próby kontaktów płciowych. Nie było u pozwanej żadnej awersji do mężczyzn, strony wzajemnie wyznawały sobie miłość - interpretacja wyłożona przez biegłego II instancji nie wydaje się przylegać do rzeczywistości. Pozwana proszona o wskazanie, do jakich obowiązków małżeńskich była niezdolna, podaje: „Nie byłam zdolna do współżycia cielesnego, a on miał duże wymagania w tej dziedzinie". Na innym miejscu mówi o propozycjach miłości francuskiej i o pragnieniu doznań ze strony męża takich, by mógł opowiadać o tym w wojsku. Jednak te wyjaśnienia sugerują, że nie przedślubne, lecz poślubne wydarzenia wywarly wplyw na klopoty stron we wspólżyciu płciowym. Trudno natomiast zaliczyć do przesłanek wniosku o niezdolności do podjęcia istotnych obowiązków małżeńskich przytoczoną przez pozwaną opinię rodziców powoda, jakoby byla niezdolna ,do wypełniania takich obowiązków domowych jak gotowanie czy sprzątanie".

Zdaniem Sądu brak przeslanek wniosku o niezdolności pozwanej do podjęcia istotnych obowiązków małżeńskich. Opinia bieglego II instancji to konstrukcja wprawdzie spójna, ale tylko hipotetyczna, nie oparta na podstawach procesowo udowodnionych. Nie bez znaczenia pozostaje też to, że - jak zeznaje pozwana - rozmowy z obecnym partnerem sprawily, że obecnie jest bezspornie w pelni zdolna do wypełnienia obowiązków małżeńskich. Byłaby to więc niezdolność, którą przezwyciężono dzięki rozmowom z partnerem? Niezdolność, o którą chodzi, nie musi być wprawdzie nieuleczalna ani trwała, ale nie widać, dlaczego można by mówić o niezdolności pozwanej akurat w stosunku do powoda, wobec którego nie miała żadnych urazów. Wyliczane w wyroku II instancji fakty negatywne, jak niepodjęcie obowiązków, brak nawiązania więzi, poczucie wyobcowania, znajdują wytłumaczenie w zeznaniu pozwanej: „Nie byliśmy razem, bo był w wojsku”.

5. Sąd docenia starania pozwanej o uregulowanie swej sytuacji kanonicznej. Pierwsza skarga wniesiona przez nią nosi datę 21.3.1991, została przedłożona w pięć i pół lat po ślubie. Małżeństwo stron trwato bardzo krótko i podejrzenia o jego nieważność rzeczywiście mogly się nasunąć, wszak nie tak wygląda „normalne” małżeństwo. (Być mo- 
że właśnie dlatego, nie widząc innych przyczyn rozpadu, biegły powołany w II instancji dogrzebał się nieuświadomionego urazu). Sąd jest jednak wladny orzekać tylko z określonego tytułu. Nie udało się rozwiązać wątpliwości, jakie nasuwa wyrok II instancji. Doceniając - powtórzmy - zachody pozwanej Sąd musi jednak traktować na serio zasadę nierozerwalności małżeńskiej. Sąd sprzeniewierzyłby się prawdzie, gdyby wybiórczo potraktował materiał dowodowy. Nie udało się rozwiać wątpliwości, jakie nasuwa wyrok orzekający nieważność małżeństwa z tytułu niezdolności pozwanej do podjęcia istotnych obowiązków małżeńskich.

Wobec takiego stanu sprawy Sąd orzeka, że nie udowodniono nieważności małżeństwa z tytułu niezdolności pozwanej do podjęcia istotnych obowiązków małżeńskich. Tym samym Sąd uchyla wyrok Trybunalu II instancji. 